\title{
Nephrotoxicity Evaluation in Outpatients Treated with Cisplatin-Based Chemotherapy Using a Short Hydration Method
}

\author{
Songül Tezcan ${ }^{1 *}$, Fikret Vehbi Izzettin ${ }^{1}$, Mesut Sancar ${ }^{1}$, Perran Fulden Yumuk ${ }^{2}$, Serdar Turhal ${ }^{2}$ \\ ${ }^{1}$ Clinical Pharmacy Department, Faculty of Pharmacy, Marmara University, Istanbul, Turkey; ${ }^{2}$ Oncology Department, Faculty of \\ Medicine, Marmara University, Istanbul, Turkey. \\ Email: *songulbutur@hotmail.com, fvizzettin@hotmail.com, sancarmesut@yahoo.com, fuldenyumuk@yahoo.com, \\ turhal@superonline.com
}

Received April $6^{\text {th }}, 2013$; revised May $10^{\text {th }}, 2013$; accepted May $18^{\text {th }}, 2013$

Copyright (C) 2013 Songül Tezcan et al. This is an open access article distributed under the Creative Commons Attribution License, which permits unrestricted use, distribution, and reproduction in any medium, provided the original work is properly cited.

\begin{abstract}
Background: To evaluate cisplatin-induced nephrotoxicity in outpatients receiving chemotherapy with cisplatin alone or in combination with other agents using a short hydration method. Methods: Forty-nine patients enrolled in the study were monitored during 3 cycles of chemotherapy. Cisplatin was given in $1000 \mathrm{~mL}$ of $0.9 \% \mathrm{NaCl}$ solution for $90 \mathrm{~min}$ as an intravenous infusion. Renal parameters were evaluated before and after each chemotherapy cycle, and 6 weeks after the completion of treatment. Results: Blood urea nitrogen, creatinine, and cystatin C levels increased significantly during the 3 cycles of chemotherapy, whereas sodium and potassium levels decreased significantly. Magnesium and calcium levels decreased only during the second cycle of chemotherapy. Significant increases in uric acid level were observed during the 1st and 3rd cycles, and 6 weeks after the completion of treatment. Conclusions: The method used in our study shows minimal changes in renal functions. To effectively monitor nephrotoxicity, renal parameters and electrolyte levels should be measured before and after each cisplatin based chemotherapy cycle. More investigations are required to evaluate this method with higher doses of cisplatin.
\end{abstract}

Keywords: Cisplatin; Nephrotoxicity; Clinical Pharmacy; Oncology Pharmacy; Chemotherapy

\section{Introduction}

Oncology pharmacy is area of interest of clinical pharmacy and oncology pharmacist included in the multidisciplinary care of cancer patients [1,2]. An important role of oncology pharmacist's is to monitor and to prevent the adverse effects of chemotherapy [3,4]. Some antineoplastic drugs associated with renal toxicity include cisplatin, carboplatin and high dose methotrexate [5]. The assessment of renal function and electrolyte levels, helps to prevent irreversible renal damage caused by nephrotoxic drugs $[6,7]$.

Cisplatin is a platin-based antineoplastic agent [8] that also has immunosuppressive, radiosensitive, and antimicrobial properties [9]. It is used for the therapy of solid tumors, such as testicular tumors, advanced ovarian cancer, cancers of the bladder, cervix, and esophagus, lung cancer, and osteogenic sarcomas [10]. Cisplatin is used

${ }^{*}$ Corresponding author. alone and in combination with other antineoplastic agents.

Cisplatin toxicity may cause ototoxic effects, peripheral neuropathy, and bone marrow suppression [10]. It's most serious and dose-limiting adverse effect is nephrotoxicity [11-13]. Among the patients that receive a single dose $\left(50 \mathrm{mg} \cdot \mathrm{m}^{-2}\right)$ of cisplatin, nephrotoxicity is observed in $28 \%-36 \%$. Although this side effect is transient, depending on the dose and cumulative effect it can lead to acute tubular necrosis $[9,14,15]$. Moreover, it can cause glomerular damage via its negative effect on the glomerular filtration rate $[11,16]$.

Sufficient hydration in patients before and after chemotherapy can prevent the accumulation of cisplatin in the tubules $[9,10]$. The method of hydration, as well as its quantity and duration vary according to the dose of cisplatin administered. In patients that receive low doses of cisplatin $\left(25-35 \mathrm{mg} \cdot \mathrm{m}^{-2}\right)$ oral hydration is adequate; however, in those that receive high doses of cisplatin 
$\left(>50 \mathrm{mg} \cdot \mathrm{m}^{-2}\right)$ intravenous hydration and oral hydration are necessary. Intravenous administration of mannitolan osmotic diuretic - prevents over retention of cisplatin in the kidneys [11,17].

The literature includes several studies on cisplatin nephrotoxicity, including evaluation and prevention of cisplatin-induced nephrotoxicity. Maintenance of adequate hydration is critical, especially for the prevention of nephrotoxicity; however, there is no standardization of hydration protocols [18-20]. As such, the present study aimed to evaluate cisplatin treatment protocols in outpatients with a short hydration method by monitoring renal function parameters.

\section{Material and Methods}

The study included 52 cancer patients undergoing cisplatin-based chemotherapy at the Marmara University Hospital, all were informed about the study, agreed to participate. The study protocol was approved by the Marmara University, School of Medicine Ethics Committee (protocol No. MAR-SBY-2007-0026). The study was conducted between February 2008 and January 2009. Data including name, address, phone number, age, gender, level of education, concomitant diseases, and treatment protocol, were obtained from patient records. In total, 3 patients dropped out of the study while undergoing chemotherapy; thus, the study was completed with the remaining 49 patients. Of the 49 patients that completed the study, 47 received chemotherapy for the first time and were treated with cisplatin alone or in combination with other agents, and 2 patients that were previously diagnosed as lung metastasis received cisplatinbased combination chemotherapy for the second time.

\subsection{Cisplatin Administration}

The mean quantity of cisplatin administered was $60-100$ $\mathrm{mg} \cdot \mathrm{m}^{-2}$. The cisplatin-based protocols were administered once every $21 \mathrm{~d}$. Prior to cisplatin infusion, intravenous infusion of $8 \mathrm{mg}$ of dexamethasone (Dekort ${ }^{\circledR}$ ) and $3 \mathrm{mg}$ of granisetron $\left(\mathrm{Kytril}^{\mathbb{B}}\right)$ in $150 \mathrm{~mL}$ of $0.9 \% \mathrm{NaCl}$ solution for 15 min was administered as premedication to prevent nausea and vomiting. Following this procedure, cisplatin dose calculated according to the body surface area was given in $1000 \mathrm{~mL}$ of $0.9 \% \mathrm{NaCl}$ solution for $90 \mathrm{~min}$ as an intravenous infusion. Following cisplatin infusion, $150 \mathrm{~mL}$ of $20 \%$ mannitol solution was administered as an intravenous infusion for $15 \mathrm{~min}$.

\subsection{Evaluation of Renal Functions}

Blood samples were collected 1 - $3 \mathrm{~d}$ prior to chemotherapy and $4-7 \mathrm{~d}$ following each chemotherapy cycle [5,21-24]. All patients were monitored during 3 cycles and the 6th week of the last cycle of cisplatin chemotherapy by measuring biochemical parameters: normal ranges were $6-23 \mathrm{mg} \cdot \mathrm{dL}^{-1}$ for blood urea nitrogen (BUN), $0.5-1.1 \mathrm{mg} \cdot \mathrm{dL}^{-1}$ for creatinine $(\mathrm{Cr}), 4-7.0$ $\mathrm{mg} \cdot \mathrm{dL}^{-1}$ for uric acid (UA), $8.4-10.5 \mathrm{mg} \cdot \mathrm{dL}^{-1}$ for calcium $(\mathrm{Ca}), 138-147 \mathrm{mEq} \cdot \mathrm{L}^{-1}$ for sodium $(\mathrm{Na}), 3.5-5.3$ $\mathrm{mEq} \cdot \mathrm{L}^{-1}$ for potassium $(\mathrm{K}), 1.2-2.6 \mathrm{mg} \mathrm{dL} \mathrm{d}^{-1}$ for magnesium $(\mathrm{Mg})$, and $0.5-0.96 \mathrm{mg} \cdot \mathrm{L}^{-1}$ for cystatin $\mathrm{C}$, respectively. The patients with the history of concomitant any disease and drug use that may affect the metabolism of magnesium, potassium, sodium, and calcium were excluded from the study.

\subsection{Statistical Analysis}

SPSS v.11.0 was used for statistical analysis. The paired samples $t$ test was used for renal function parameter values obtained during the 3 cycles of chemotherapy and 6 weeks after the 3rd cycle and the Wilcoxon test was used for the values that were not normally distributed. The correlation between the glomerular filtration rate (GFR) and creatinine was based on Pearson's correlation analysis, whereas Spearman's correlation analysis was used to determine the correlation between the GFR and cystatin $\mathrm{C}$ values that were not normally distributed. The level of statistical significance was set at $\mathrm{P}<0.05$.

\section{Results}

\subsection{Patient Characteristics}

Patient demographic data are given in Table 1. The mean dose of cisplatin administered during each of the 3 chemotherapy cycles was $120.30 \pm 20.4 \mathrm{mg}, 119.76 \pm 24.7$ $\mathrm{mg}$, and $123.84 \pm 16.01 \mathrm{mg}$, respectively. The total cisplatin dose administered to patients that received 2 and 3 cycles of chemotherapy was $256.87 \pm 12.5 \mathrm{mg}$ and 374.0 $\pm 39.0 \mathrm{mg}$, respectively. Table 2 shows the chemotherapy regimens administered to the patients.

\subsection{Evaluation of the Renal Functions}

Renal functions were monitored throughout the 3 cycles of chemotherapy. BUN, creatinine, and uric acid levels, which were normal prior to the start of chemotherapy, increased significantly $(\mathrm{P}<0.05)$ during the first week of cisplatin treatment and 6 weeks after the last cycle of cisplatin-based chemotherapy; however, all three parameters remained within the limits of the reference values (Table 3).

The cystatin $\mathrm{C}$ levels were found above the reference values $\left(0.5-0.96 \mathrm{mg} \cdot \mathrm{L}^{-1}\right)$ in $59.5 \%$ of patients (mean of the cystatin C: $1.01 \pm 0.44)$ after the 1 st cycle, in $69.1 \%$ of patients (mean of the cystatin C: $1.07 \pm 0.30$ ) after the 2nd cycle and in $50 \%$ of patients (mean of the cystatin 
Table 1. Patients' characteristics

\begin{tabular}{|c|c|c|c|}
\hline Characteristics & & Number of patients (49) & $(\%)$ \\
\hline Age (year) & $\begin{array}{l}\text { Mean } \pm \text { SD: } 54.55 \pm 12.13 \\
\text { Range: } 19-76\end{array}$ & & \\
\hline Sex & $\begin{array}{l}\text { Male } \\
\text { Female }\end{array}$ & $\begin{array}{l}35 \\
14\end{array}$ & $\begin{array}{l}71.4 \\
28.6\end{array}$ \\
\hline Disease & $\begin{array}{l}\text { NSCLC } \\
\text { Head-neck } \\
\text { Stomach } \\
\text { Breast } \\
\text { Biliary }\end{array}$ & $\begin{array}{l}23 \\
15 \\
7 \\
2 \\
2\end{array}$ & $\begin{array}{c}46.9 \\
30.6 \\
14.3 \\
4.1 \\
4.1\end{array}$ \\
\hline Education level & $\begin{array}{l}\text { No education } \\
\text { Primary school } \\
\text { Secondary education } \\
\text { High school } \\
\text { University }\end{array}$ & $\begin{array}{c}3 \\
25 \\
11 \\
7 \\
3\end{array}$ & $\begin{array}{c}6.1 \\
51.0 \\
22.4 \\
14.3 \\
6.1\end{array}$ \\
\hline Number of cycles & $\begin{array}{l}1 \text { cycle } \\
2 \text { cycles } \\
3 \text { cycles }\end{array}$ & $\begin{array}{c}8 \\
16 \\
25\end{array}$ & $\begin{array}{l}16.3 \\
32.7 \\
51.0\end{array}$ \\
\hline
\end{tabular}

Table 2. Chemotherapy regimens administered to the patients.

\begin{tabular}{lcc}
\hline & Number of patients & $\%$ \\
\hline cis-eto: Cisplatin-etoposide & 14 & 28.6 \\
cis-gem: cisplatin-gemcitabine & 10 & 20.4 \\
cis-fu: cisplatin-5-fluorourasil & 3 & 6.1 \\
tcf: docetaxel (Taxotere ${ }^{\circledR}$ )-cisplatin-5-fluorourasil & 7 & 14.3 \\
cis: cisplatin & 8 & 16.3 \\
ecf: epirubicin-cisplatin-5-fluorourasil & 4 & 8.2 \\
cis-adria: cisplatin-adriamycin & 1 & 2.0 \\
cap: cyclophosphamide-adriamycin-platin (cisplatin) & 1 & 2.0 \\
cis-pem:cisplatin-pemetrexed & 1 & 2.0 \\
\hline
\end{tabular}

Table 3. Patients' renal parameters.

\begin{tabular}{|c|c|c|c|c|c|c|c|}
\hline \multirow{2}{*}{$\begin{array}{l}\text { Biochemical } \\
\text { parameters and } \\
\text { referans values }\end{array}$} & \multicolumn{2}{|c|}{ 1. cycle } & \multicolumn{2}{|c|}{ 2. cycle } & \multicolumn{2}{|c|}{ 3. cycle } & \multirow{2}{*}{$\begin{array}{c}\begin{array}{c}\text { Aftercisplatin } \\
\text { therapy }\end{array} \\
\text { ' at sixth week }_{\text {ath }}(\text { mean } \pm \text { SD })\end{array}$} \\
\hline & $\begin{array}{l}{ }^{\wedge} \text { before the } \\
\text { treatment } \\
\dagger(\text { mean } \pm \mathrm{SD})\end{array}$ & $\begin{array}{c}* \text { after the } \\
\text { treatment } \\
(\text { mean } \pm \mathrm{SD})\end{array}$ & $\begin{array}{c}{ }^{\wedge} \text { before the } \\
\text { treatment } \\
(\text { mean } \pm \mathrm{SD})\end{array}$ & $\begin{array}{c}\text { *after the } \\
\text { treatment } \\
(\text { mean } \pm \mathrm{SD})\end{array}$ & $\begin{array}{l}{ }^{\wedge} \text { before the } \\
\text { treatment } \\
{ }^{\dagger}(\text { mean } \pm \mathrm{SD})\end{array}$ & $\begin{array}{c}\text { after the } \\
\text { treatment } \\
+(\text { mean } \pm \mathrm{SD})\end{array}$ & \\
\hline $\begin{array}{l}\text { BUN } \\
(6-23 \mathrm{mg} / \mathrm{dL})\end{array}$ & $\begin{array}{c}* * 15.16 \pm 4.30 \\
\mathrm{n}: 43\end{array}$ & $\begin{array}{c}* * 21.30 \pm 6.21 \\
\mathrm{n}: 43\end{array}$ & $\begin{array}{c}* * 16.71 \pm 5.79 \\
\mathrm{n}: 35\end{array}$ & $\begin{array}{c}* * 21.18 \pm 6.71 \\
\mathrm{n}: 35\end{array}$ & $\begin{array}{c}* * 15.27 \pm 4.79 \\
\mathrm{n}: 26\end{array}$ & $\begin{array}{c}* * 22.81 \pm 7.61 \\
\mathrm{n}: 26\end{array}$ & $\begin{array}{c}* 19.00 \pm 7.07 \\
\mathrm{n}: 20\end{array}$ \\
\hline $\begin{array}{l}\text { Creatinine } \\
(0.5-1.1 \mathrm{mg} / \mathrm{dL})\end{array}$ & $\begin{array}{c}{ }^{*} 0.77 \pm 0.19 \\
\mathrm{n}: 43\end{array}$ & $\begin{array}{c}{ }^{*} 0.83 \pm 0.19 \\
\mathrm{n}: 43\end{array}$ & $\begin{array}{c}{ }^{*} 0.81 \pm 0.20 \\
\mathrm{n}: 34\end{array}$ & $\begin{array}{c}{ }^{*} 0.86 \pm 0.22 \\
\mathrm{n}: 34\end{array}$ & $\begin{array}{c}{ }^{*} 0.74 \pm 0.23 \\
\mathrm{n}: 25\end{array}$ & $\begin{array}{c}{ }^{*} 0.83 \pm 0.21 \\
\mathrm{n}: 25\end{array}$ & $\begin{array}{c}{ }^{*} 0.87 \pm 0.32 \\
\mathrm{n}: 20\end{array}$ \\
\hline $\begin{array}{l}\text { Uric acid } \\
(3.4-7.0 \mathrm{mg} / \mathrm{dL})\end{array}$ & $\begin{array}{c}* 4.27 \pm 1.21 \\
\mathrm{n}: 41\end{array}$ & $\begin{array}{c}* 4.79 \pm 1.54 \\
\mathrm{n}: 41\end{array}$ & $\begin{array}{c}4.58 \pm 1.51 \\
n: 31\end{array}$ & $\begin{array}{c}4.91 \pm 1.64 \\
n: 31\end{array}$ & $\begin{array}{c}* 4.60 \pm 1.55 \\
\mathrm{n}: 24\end{array}$ & $\begin{array}{c}* 5.00 \pm 1.42 \\
\mathrm{n}: 24\end{array}$ & $\begin{array}{c}* 4.78 \pm 1.92 \\
\text { n: } 19\end{array}$ \\
\hline $\begin{array}{l}\text { Sodium } \\
(\mathrm{Na}) 138 \text { - } 147 \\
\mathrm{mEq} / \mathrm{L}\end{array}$ & $\begin{array}{c}* * 139.26 \pm 4.73 \\
\mathrm{n}: 43\end{array}$ & $\begin{array}{c}* * 136.96 \pm 3.91 \\
\mathrm{n}: 43\end{array}$ & $\begin{array}{c}* * 139.73 \pm 2.5 \\
\mathrm{n}: 34\end{array}$ & $\begin{array}{c}* * 135.18 \pm 5.5 \\
\mathrm{n}: 34\end{array}$ & $\begin{array}{c}* * 139.28 \pm 4.05 \\
\mathrm{n}: 24\end{array}$ & $\begin{array}{c}\text { ** } 135.71 \pm 4.75 \\
\mathrm{n}: 24\end{array}$ & $\begin{array}{c}139.63 \pm 2.52 \\
\mathrm{n}: 19\end{array}$ \\
\hline $\begin{array}{l}\text { Potassium (K) } \\
(3.5-5.3 \mathrm{mEq} / \mathrm{L})\end{array}$ & $\begin{array}{c}{ }^{*} 4.53 \pm 0.55 \\
\mathrm{n}: 43\end{array}$ & $\begin{array}{c}{ }^{*} 4.29 \pm 0.61 \\
\mathrm{n}: 43\end{array}$ & $\begin{array}{c}{ }^{*} 4.64 \pm 0.59 \\
\mathrm{n}: 32\end{array}$ & $\begin{array}{c}{ }^{*} 4.28 \pm 0.57 \\
\mathrm{n}: 32\end{array}$ & $\begin{array}{c}{ }^{*} 4.58 \pm 0.53 \\
\mathrm{n}: 24\end{array}$ & $\begin{array}{c}{ }^{*} 4.29 \pm 0.53 \\
\mathrm{n}: 24\end{array}$ & $\begin{array}{c}4.58 \pm 0.40 \\
\mathrm{n}: 19\end{array}$ \\
\hline $\begin{array}{l}\text { Magnesium (Mg) } \\
(1.2-2.6 \mathrm{mg} / \mathrm{dL})\end{array}$ & $\begin{array}{c}2.11 \pm 0.25 \\
\mathrm{n}: 41\end{array}$ & $\begin{array}{c}2.17 \pm 0.20 \\
\mathrm{n}: 41\end{array}$ & $\begin{array}{c}* 2.06 \pm 0.17 \\
\mathrm{n}: 33\end{array}$ & $\begin{array}{c}* 1.96 \pm 0.23 \\
\mathrm{n}: 33\end{array}$ & $\begin{array}{c}1.99 \pm 0.25 \\
\mathrm{n}: 24\end{array}$ & $\begin{array}{c}1.93 \pm 0.27 \\
\mathrm{n}: 24\end{array}$ & $\begin{array}{c}2.06 \pm 0.26 \\
\mathrm{n}: 19\end{array}$ \\
\hline $\begin{array}{l}\text { Calcium } \\
(8.4-10.5 \mathrm{mg} / \mathrm{dL})\end{array}$ & $\begin{array}{c}8.94 \pm 0.65 \\
n: 43\end{array}$ & $\begin{array}{c}8.89 \pm 0.64 \\
n: 43\end{array}$ & $\begin{array}{c}{ }^{*} 9.00 \pm 0.39 \\
\mathrm{n}: 34\end{array}$ & $\begin{array}{c}* 8.7 \pm 0.63 \\
n: 34\end{array}$ & $\begin{array}{c}8.90 \pm 0.52 \\
\mathrm{n}: 24\end{array}$ & $\begin{array}{c}8.80 \pm 0.61 \\
\mathrm{n}: 24\end{array}$ & $\begin{array}{c}9.07 \pm 0.47 \\
\mathrm{n}: 19\end{array}$ \\
\hline
\end{tabular}

${ }^{\wedge}$ Before therapy: 1 - 3 days before chemotherapy; *after therapy: 4 - 7 days after chemoyherapy; "at sixth week: at sixth week after cisplatin therapy; ${ }^{\dagger}($ mean \pm $\mathrm{SD}) ;{ }^{*} \mathrm{P}<0.05 ;{ }^{* *} \mathrm{P}<0.001$. 
C: $1.03 \pm 0.35$ ) of the patients after the 3 rd cycle. There were also increases in cystatin $\mathrm{C}$ levels 6 weeks after the last cycle of cisplatin-based chemotherapy which was not statistically significant.

Patients' electrolyte levels were evaluated during 3 cycles and the 6th week of last cycle of chemotherapy. During the 3 cycles of cisplatin-based chemotherapy decreases in potassium, magnesium, calcium and sodium levels were observed (Table 3). Sodium and potassium levels decreased significantly, whereas magnesium and calcium levels decreased only in the second cycle of chemotherapy $(\mathrm{P}<0.05)$. The decreases in the Na levels were found in $56.8 \%$ of patients (mean of the Na levels: $136.96 \pm 3.91 \mathrm{mEq} \cdot \mathrm{L}^{-1}$ ) after the 1 st cycle, in $58.8 \%$ of patients (mean of the Na levels: $135.18 \pm 5.5 \mathrm{mEq} \cdot \mathrm{L}^{-1}$ ) after the 2 nd cycle and in $72 \%$ of the patients (mean of the Na levels: $135.71 \pm 4.75 \mathrm{mEq} \cdot \mathrm{L}^{-1}$ ) after the 3 rd cycle.

Estimated creatinine clearance calculated according to the Cockcroft-Gault formula [(140 - age $) \times$ weight/(serum creatinine $\times 72$ ); for women this ratio was multiplied by 0.85 ] is expressed as the GFR. Accordingly, the GFR following the 1st, 2nd and 3rd cycles of chemotherapy were significantly lower than those before the start of chemotherapy $(\mathrm{P}<0.01)$. After the 1 st cycle of chemotherapy $45.5 \%$ of the patients had minimal changes in renal functions versus $32 \%$ after the 3 rd cycle. The GFR 6 weeks after the end of the 3rd cycle of cisplatin che- motherapy decreased by 7\%; however, the difference was not statistically significant $(\mathrm{P}>0.05)$ (Table 4).

Pearson's correlation analysis showed that prior to the start of chemotherapy there was a strong negative correlation between the GFR and creatinine level (rho: -0.701 , $\mathrm{P}<0.001$ ), and Spearman's correlation analysis showed that prior to the start of chemotherapy there was a strong negative correlation between the GFR and cystatin C level (rho: $-0.468, \mathrm{P}<0.05$ ) (Figure 1).

Pearson's correlation analysis showed that there was a strong negative correlation between the GFR and creatinine level prior to the third cycle of chemotherapy (rho: $-0.747, \mathrm{P}<0.001$ ), and Spearman's correlation analysis showed that there was a strong negative correlation between the GFR cystatin $\mathrm{C}$ level prior to the third cycle of chemotherapy (rho: $-0.500, \mathrm{P}<0.05$ ) (Figure 2).

\section{Discussion}

The European Society of Clinical Pharmacy (ESCP) Special Interest Group on Cancer Care published guidelines for the prevention of cisplatin nephrotoxicity in 2008 [25]. In consideration of these guidelines, patients in our study were monitored $2-3 \mathrm{~d}$ prior to the start of each chemotherapy cycle and $4-7 \mathrm{~d}$ following each cycle for serum creatinine, BUN, and uric acid levels. These parameters were statistically increased $(\mathrm{P}<0.05)$;

Table 4. The GFR before and after the 1st and 3rd cycles of chemotherapy.

\begin{tabular}{|c|c|c|c|c|c|c|c|c|}
\hline & \multicolumn{2}{|c|}{ 1st Cycle } & \multicolumn{2}{|c|}{ 2nd Cycle } & \multicolumn{2}{|c|}{ 3rd Cycle } & \multirow[b]{2}{*}{ Before 1st cycle } & \multirow[b]{2}{*}{ at 6th week } \\
\hline & Before & After & Before & After & Before & After & & \\
\hline GFR & $\begin{array}{c}* * 109.62 \pm 5.12 \\
n=43\end{array}$ & $\begin{array}{c}* * 99.99 \pm 4.7 \\
n=43\end{array}$ & $\begin{array}{c}* * 105.86 \pm 6.72 \\
n=27\end{array}$ & $\begin{array}{c}* * 98.21 \pm 6.12 \\
n=27\end{array}$ & $\begin{array}{c}* * 118.63 \pm 9.0 \\
n=25\end{array}$ & $\begin{array}{c}* * 104.90 \pm 8.0 \\
n=25\end{array}$ & $\begin{array}{c}{ }^{*} 111.98 \pm 10.52 \\
n=8\end{array}$ & $\begin{array}{c}* 103.69 \pm 11.69 \\
n=8\end{array}$ \\
\hline
\end{tabular}

${ }^{\wedge}$ At 6 th week after 3 rd cycles of cisplatin; ${ }^{*} \mathrm{P}<0.05 ;{ }^{* *} \mathrm{P}<0.01$.

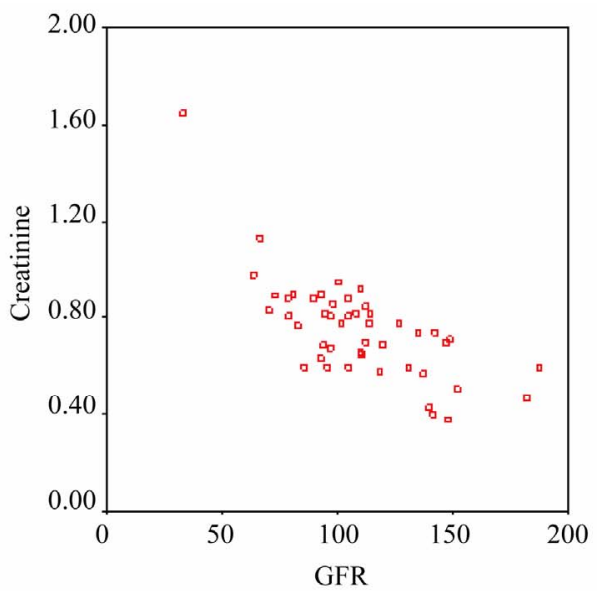

(a)

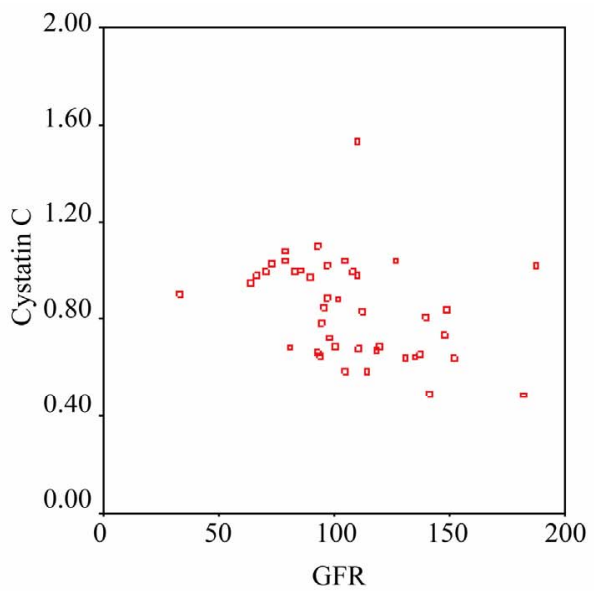

(b)

Figure 1. (a) The correlation between the creatinine level and GFR prior to the first cycle of chemotherapy; (b) The correlation between the cystatin C level and GFR prior to the first cycle of chemotherapy. 


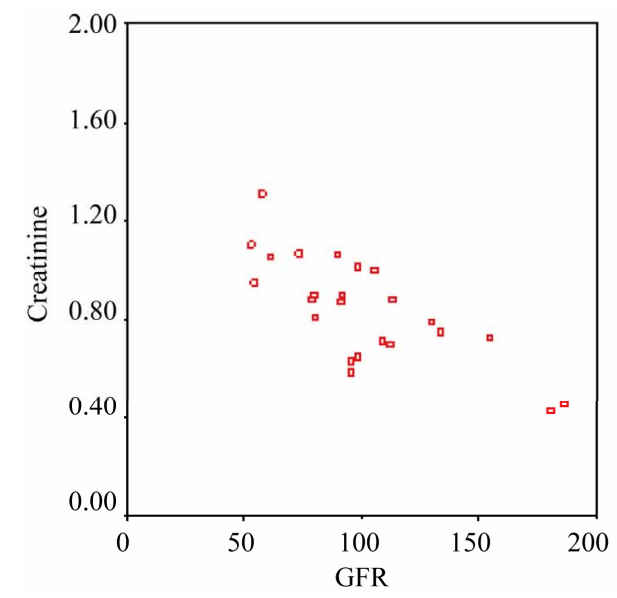

(a)

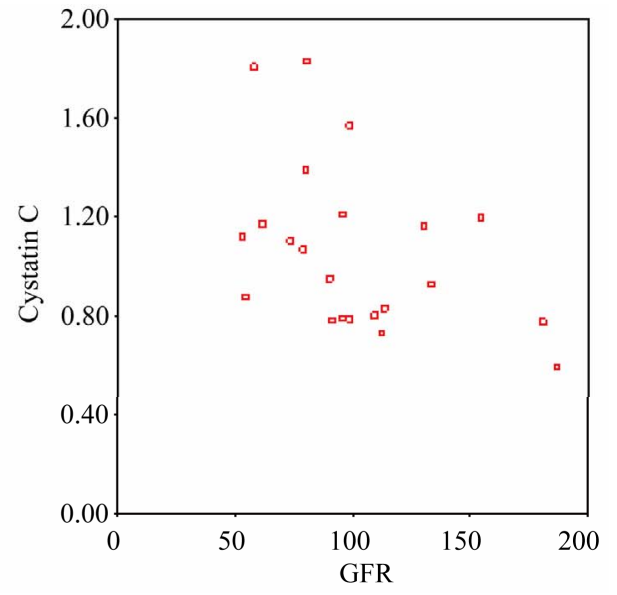

(b)

Figure 2. (a) The creatinine level and GFR following the third cycle of chemotherapy; (b) The cystatin C level and GFR following the third cycle of chemotherapy.

however, remained within the limits of the reference values.

In the literature there are many studies to evaluate the different hydration methods. A retrospective study that included patients who received $75 \mathrm{mg} \cdot \mathrm{m}^{-2}$ of cisplatin and hydration with $2 \mathrm{~L}$ of fluid reported that the method of hydration used was efficacious [20]. Another study reported that hydration with isotonic solution and isotonic solution plus furosemide resulted in less cisplatin-induced nephrotoxicity than compared to hydration with isotonic solution plus mannitol [19]. In the present study cisplatin was infused for $90 \mathrm{~min}$ in $1000 \mathrm{~mL}$ of isotonic solution. Following infusion, $30 \mathrm{mg}$ of mannitol was infused for $15 \mathrm{~min}$ in $150 \mathrm{cc}$ of isotonic solution. The GFR level in our patients decreased significantly after the first cycle of cisplatin-based chemotherapy (GFR: $109.62 \pm 5.12$ vs $99.99 \pm 4.7 \mathrm{n}=43 ; \mathrm{P}<0.01)$. Again, after the third cycle of chemotherapy, the GFR decreased significantly, as compared to the pre chemotherapy value (GFR: $118.63 \pm 9.0$ vs $104.90 \pm 8.0 ; \mathrm{n}=25 ; \mathrm{P}<0.01$ ). The GFR levels 6 weeks after completion of cisplatinbased chemotherapy was significantly lower than the pretreatment value (GFR: $111.58 \pm 9.28$ vs $86.59 \pm 8.20$; P $<0.05)$. Despite the observed change, the GFR remained within normal limits and did not negatively affect the patients' clinical presentation.

Hypomagnesemia and hyperglycaemia due to cisplatin-induced renal toxicity are common clinical conditions. Nicholas et al. reported that $87 \%$ of patients that underwent cisplatin-based chemotherapy had hypomagnesemia [26]. Another study compared oral and intravenous magnesium prophylaxis among patients treated with cisplatin that were divided into 3 groups. Group 1 was not given magnesium supplementation, Group 2 received intravenous magnesium, and Group 3 received oral magnesium supplementation. Patients were monitored throughout 4 cycles of chemotherapy and their magnesium levels were recorded and evaluated. The hypomagnesemia was observed in 33\% of Group 2, 44\% of Group 3 , and $90 \%$ of Group 1 [27].

Our hospital's treatment regimen does not include routine magnesium or potassium supplementation (intravenously or orally) before or after cisplatin infusion. In our study during the 3 cycles of cisplatin-based chemotherapy, sodium and potassium levels decreased significantly, whereas magnesium and calcium levels decreased only during the second cycle of chemotherapy $(\mathrm{P}<0.05)$. However, potassium, magnesium and calcium levels remained within the limits of reference values. The patients' electrolyte levels prior to the start of cisplatinbased chemotherapy and 6 weeks after completion of the therapy showed that they reverted to pre-treatment levels, indicating that the observed cisplatin-induced nephrotoxicity was transient.

The present study also monitored serum cystatin C levels and determined its correlation with the GFR. In cancer patients Stabuck et al. reported that there was a stronger correlation between creatinine clearance and cystatin $\mathrm{C}$ than between serum creatinine and cystatin $\mathrm{C}$ [28]. Many trials reported that the cystatin $\mathrm{C}$ level is more efficient than the serum creatinine level for evaluating cisplatin-induced decreases in the GFR [22,29,30]. The results of these studies indicate that the GFR calculated according to the Cockcroft-Gault formula and cystatin $\mathrm{C}$ level show a more parallel relationship than the serum creatinine level. In our study there was a strong correlation between the GFR and cystatin $\mathrm{C}$ level, but the correlation between the GFR and creatinine level was much stronger (cystatin $\mathrm{C}$ and the GFR: rho: $-0.468, \mathrm{P}<$ 0.05; creatinine and the GFR: rho: $-0.701, \mathrm{P}<0.001$ ). 
In conclusion, cisplatin-induced changes in renal function using our method were transient, did not cause permanent damage to the kidneys, and did not negatively affect the patients' clinical presentation. But it is emphasizing in the literature, when cisplatin based cycle numbers increased, depending on cumulative dose of cisplatin the changes in renal function can be permanent. Thus we suggest that patients treated with large doses of cisplatin should be monitored for nephrotoxicity. More investigations for analyzing cisplatin hydration methods used at different centers can help for standardization of hydration methods.

\section{REFERENCES}

[1] D. H. Honda, "Role of the Clinical Pharmacist in Oncology Care," Frontiers of Radiation Therapy and Oncology, Vol. 15, 1980, pp. 157-161.

[2] D. M. Stull, A. Iannucci and R. Bertin, "Board-Certified Oncology Pharmacists: Partners in the Multidisciplinary Care of Cancer Patients," Community Oncology, Vol. 3, No. 5, 2006, pp. 284-286. doi:10.1016/S1548-5315(11)70696-9

[3] E. R. Bremberg, C. Hising, U. Nylén, H. Ehrsson and S. Eksborg, "An Evaluation of Pharmacist Contribution to an Oncology Ward in a Swedish Hospital," Journal of Oncology Pharmacy Practice, Vol. 12, No. 2, 2006, pp. 75-81. doi:10.1177/1078155206070412

[4] C. D. Duong and J. Y. Loh, "Laboratory Monitoring in Oncology," Journal of Oncology Pharmacy Practice, Vol. 12, No. 4, 2006, pp. 223-236. doi:10.1177/1078155206072982

[5] J. M. Medina and C. Fausel, "Cancer Treatment and Chemotherapy," In: J. Dipiro, R. Tolberto, G. Yee, G. Matzke, B. Wells and L. Posey, Eds., Pharmacotherapy a Pathophsiologic Approach, McGrow-Hill Medical Publishing Division, New York, 2005, p. 2100.

[6] P. E. Kintzel, "Anticancer Drug-Induced Kidney Disorders: Incidence, Prevention and Management," Drug safety, Vol. 24, No. 1, 2001, pp. 19-38. doi:10.2165/00002018-200124010-00003

[7] G. Giaccone, M. Donadio, P. Ferrati, L. Ciuffreda, M. Bagatella, M. Gaddi and A. Calciati, "Disorders of Serum Electrolytes and Renal Function in Patients Treated with Cis-Platinum on an Outpatient Basis," European Journal of Cancer \& Clinical Oncology, Vol. 2, No. 4, 1985, pp. 433- 437. doi:10.1016/0277-5379(85)90033-1

[8] O. Kayaalp, “Antibiyotikler ve Diğer Kemoterapötikler," İn: O. Kayaalp, Ed., Tıbbi Farmakoloji, Hacettepe Taş, Ankara, 2005, pp. 333-334.

[9] G. K. McEvoy, E. K. Snow and L. Kester, In: G. K. McEvoy, E. K. Snow and L. Kester, "AHFS Drug Information," American Society of Health-System Pharmacist, 2006, pp. 979-984.

[10] O. Kayaalp "Türkiye İlaç Kılavuzu TİK-6 2011-12 Formüleri,” Pelikan Yayıncılık, Ankara, 2005, p. 598.
[11] X. Yao, K. Panichpisal, N. Kurtzman and K. Nugent, "Cisplatin Nephrotoxicity: A Review," The American Journal of the Medical Sciences, Vol. 334, No. 2, 2007, pp. 115-124. doi:10.1097/MAJ.0b013e31812dfe1e

[12] J. Gaedeke, L. M. Fels, C. Bokemeyer, U. Mengs, H Stolte and H. Lentzen, "Cisplatin Nephrotoxicity and Protection by Silibinin," Nephrology Dialysis Transplantation, Vol. 11, No. 1, 1996, pp. 55-62. doi:10.1093/oxfordjournals.ndt.a027066

[13] M. S. Razzaque, "Cisplatin Nephropathy: Is Cytotoxicity Avoidable?" Nephrology Dialysis Transplantation, Vol. 22, No. 8, 2007, pp. 2112-2116. doi:10.1093/ndt/gfm378

[14] D. M. Townsend, M. Deng, L. Zhang, M. G. Lapus and M. H. Hanigan, "Metabolism of Cisplatin to a Nephrotoxin in Proximal Tubule Cells," Journal of the American Society of Nephrology, Vol. 14, No. 1, 2003, pp. 1-10. doi:10.1097/01.ASN.0000042803.28024.92

[15] N. V. Lyubimova, S. V. Topchieva, S. G. Averinova, A. V. Kashkadaeva, V. A. Gorbunova, S. V. Shiryaev and N. E. Kushlinskii, "Modern Methods for Diagnosis and Monitoring of Nephrotoxicity during Antitumor Therapy with Platinum Derivatives," Bulletin of Experimental Biology and Medicine, Vol. 130, No. 3, 2000, pp. 886-891. doi:10.1007/BF02682261

[16] C. M. Keaney and J. E. Springate, "Cancer and the Kidney," Adolescent Medicine Clinics, Vol. 16, No. 1, 2005, pp. 121-148. doi:10.1016/j.admecli.2004.09.012

[17] B. Tokgoz, "Renal Abnormalities during Malignancies and Chemotherapy Related ARF," Türk Nefroloji Diyaliz ve Transplantasyon Dergisi, Vol. 15, No. 1, 2006, pp. 7986.

[18] T. L. Cornelison and E. Reed, "Nephrotoxicity and Hydration Management for Cisplatin, Carboplatin, and Ormaplatin," Gynecologic Oncology, Vol. 50, No. 2, 1993, pp. 147-158. doi:10.1006/gyno.1993.1184

[19] J. T. Santoso, J. A. Lucci 3rd, R. L. Coleman, I. Schafer and E. V. Hannigan, "Saline, Mannitol, and Furosemide Hydration in Acute Cisplatin Nephrotoxicity: A Randomized Trial," Cancer Chemotherapy and Pharmacology, Vol. 52, No. 1, 2003, pp. 13-18. doi:10.1007/s00280-003-0620-1

[20] M. Tiseo, O. Martelli, A. Mancuso, M. P. Sormani, P. Bruzzi, R. Di Salvia, F. De Marinis and A. Ardizzoni, "Short Hydration Regimen and Nephrotoxicity of Intermediate to High-Dose Cisplatin-Based Chemotherapy for Outpatient Treatment in Lung Cancer and Mesothelioma," Tumori, Vol. 93, No. 2, 2007, pp. 138-144.

[21] B. Kömürcüoğlu, M. Büyükşirin, H. İşgüder, D. Kalenci and E. Özden, "Is it Necessary to Evaluate the Magnesium and Calcium Levels in Cisplatinum Treated Lung Cancer Patients?" Izmir Göğ̈̈s Hastanesi Dergisi, Vol. 18, No. 3, 2004, pp. 101-106.

[22] P. Benöhr, A. Grenz, J. T. Hartmann, G. A. Müller and S. Blaschke, "Cystatin C-A Marker for Assessment of the Glomerular Filtration Rate in Patients with Cisplatin Chemotherapy," Kidney and Blood Pressure Research, Vol. 29, No. 1, 2006, pp. 32-35. doi: $10.1159 / 000092485$ 
[23] E. Kurt, T. Evrensel, G. Gönüllü, Ö. Kanat, M. Demiray, M. Arslan, Ö. Ünlü, K. Dilek and O. Manavoğlu, "Cisplatin-Induced Renal Toxicity and Evaluation of the Efficacy of Synthetic Oral Prostaglandin E1 Analogue," Uludağ Üniversitesi Tıp Fakültesi Dergisi, Vol. 28, No. 2, 2002, pp. 17-20.

[24] R. T. Skeel, "Antineoplastic Drugs and Biologic Response Modifiers: Classification, Use, and Toxicity of Clinically Useful Agents," In: R. T. Skeel, Ed., Handbook of Cancer Chemotherapy, Lippincott Williams \& Wilkins, Philadelphia, 2007, pp. 693-843.

[25] V. Launay-Vacher, J. B. Rey, C. Isnard-Bagnis, G. Deray and M. Daouphars, "Prevention of Cisplatin Nephrotoxicity: State of the Art and Recommendations from the European Society of Clinical Pharmacy Special Interest Group on Cancer Care," Cancer Chemother Pharmacol, Vol. 6, No. 6, 2008, pp. 903-918. doi:10.1007/s00280-008-0711-0

[26] J. Nicholas, N. J. Vogelzang, J. L. Torkelson and B. J. Kennedy, "Hypomagnesemia, Renal Dysfunction, and Raynaud's Phenomenon in Patients Treated with Cisplatin, Vinblastine, and Bleomycin," Cancer, Vol. 56, No. 12,1985 , pp. 2765-2770. doi:10.1002/1097-0142(19851215)56:12<2765::AID-CN CR2820561208>3.0.CO;2-2
[27] M. Martin, E. Diaz-Rubio, A. Casado, J. M. Lopez Vega, J. Sastre and J. Almenarez, "Intravenous and Oral Magnesium Supplementations in the Prophylaxis of CisplatinInduced Hypomagnesemia. Results of a Controlled Trial,' American Journal of Clinical Oncology, Vol. 15, No. 4, 1992, pp. 348-351. doi:10.1097/00000421-199208000-00016

[28] B. Stabuc, L. Vrhovec, M. Stabuc-Silih and T. E. Cizej, "Improved Prediction of Decreased Creatinine Clearance by Serum Cystatin C: Use in Cancer Patients before and during Chemotherapy," Clinical Chemistry, Vol. 46, No. 2, 2000, pp. 193-197.

[29] R. Hojs, S. Bevc, R. Ekart, M. Gorenjak and L. Puklavec, "Serum Cystatin $\mathrm{C}$ as an Endogenous Marker of Renal Function in Patients with Mild to Moderate Impairment of Kidney Function," Nephrology Dialysis Transplantation, Vol. 21, No. 7, 2006, pp. 1855-1862. doi:10.1093/ndt/gf1073

[30] F. J. Hoek, F. A. Kemperman and R. T. Krediet, "A Comparison between Cystatin C, Plasma Creatinine and the Cockcroft and Gault Formula for the Estimation of Glomerular Filtration Rate," Nephrology Dialysis Transplantation, Vol. 18, No. 10, 2003, pp. 2024-2031. doi:10.1093/ndt/gfg349 